\title{
Hypoglycemia Refractory in Patient with Metastatic Gastrointestinal Stromal Tumor (GIST): Case Report and Literature Review
}

\author{
Facanha ALBP ${ }^{1}$, Junior JEBR ${ }^{1}$ and Marcos Pedro Guedes Camandaroba ${ }^{1 *}$ \\ ${ }^{1}$ Department of Clinical Oncology, Ac Camargo Cancer Center, Brazil
}

ISSN: 2637-7632

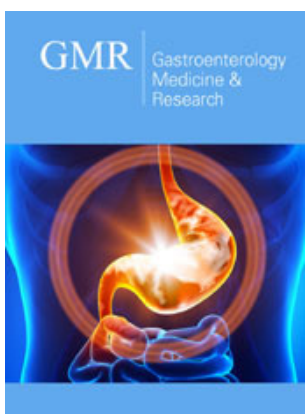

*Corresponding author: Marcos Pedro Guedes Camandaroba, Medical Oncologist, Antonio Prudente Street, São Paulo, Brazil

Submission: 毕 February 09, 2021

Published: 非 February 24, 2021

Volume 5 - Issue 4

How to cite this article: Facanha ALBP, Junior JEBR, Marcos Pedro Guedes Camandaroba. Hypoglycemia Refractory in Patient with Metastatic Gastrointestinal Stromal Tumor (GIST): Case Report and Literature Review. Gastro Med Res. 5(4) GMR. 000619. 2021.

DOI: 10.31031/GMR.2021.05.000619

Copyright@ Marcos Pedro Guedes Camandaroba, This article is distributed under the terms of the Creative Commons Attribution 4.0 International License, which permits unrestricted use and redistribution provided that the original author and source are credited.

\begin{abstract}
A case of NICTH secondary to gastrointestinal stromal tumor (GIST) is described, male patient admitted to the emergency referring asthenia and drowsiness, and measured blood glucose of $20 \mathrm{mg} / \mathrm{dL}$. Patient continued to present episodes of recurrent hypoglycemia: 33/55/32mg/dL, even with continuous reposition of $10 \%$ glucose solution. Hypoglycemia can be related to several tumors, including islet cell and non-islet cell tumors. Non-islet cell tumor hypoglycemia (NICTH) is a rare and serious complication of malignancy, and its presence is usually associated with a poor prognosis. The most common cause of this type of hypoglycemia is tumor overproduction of insulin-like growth factor II (IGF-II), which stimulates the insulin receptor, leading to decreased insulin and glucagon levels. The diagnosis of NICTH is based on clinical and laboratory findings. Patients with NICTH have low serum concentrations of insulin and C-peptide during hypoglycemia. The treatment of this condition is related to the control of the underlying neoplasia. In patients who are unable to undergo invasive procedures, the use of corticosteroids is a good treatment option, leading to normalization of glycemia. Its management is of unquestionable importance to ensure the patient's quality of life. A review of the literature on epidemiology, diagnosis and treatment of this complication follows.
\end{abstract}

Keywords: Hypoglicemia; Paraneoplastic endocrine syndromes; Gastrointestinal stromal tumors

\section{Introduction}

Several types of tumors are associated with Non-islet cell tumor hypoglycemia (NICTH), although gastrointestinal stromal tumor (GIST), is rarely involved [1,2]. These tumors are usually large and located in the chest or retroperitoneum [1]. NICTH is associated with the production of IGF-II, which stimulates the insulin receptor, leading to decreased insulin and glucagon levels, consumption of glucose by tumor cells, reduction ketogenesis, glycogenolysis and gluconeogenesis, reduction of lipolysis and glucose storage in skeletal muscles; it also binds to IGF-I receptor, leading to decreased growth factors and IGF-I levels $[3,4]$. The treatment of this condition is related to the control of the underlying neoplasia, being indicated cytoreductive surgery or tumor embolization, for patients that don't have a controlled disease with the regular treatment used for GIST (bases on tyrosine kinase inhibitors) [5,6]. In patients who are unable to undergo invasive procedures, the use of corticosteroids is a good treatment option, leading to normalization of glycemia [6,7]. Although, hypoglycemia can reoccur once they are discontinued [7]. We report a rare case of a metastatic GIST and refractory hypoglycemia, followed by a review of the diagnostic literature and treatment of this complication.

\section{Case Report}

A 50-years-old Brazilian man, diagnosed with GIST of the small intestine, was admitted to the emergency room reporting asthenia and drowsiness, in addition to abdominal pain and progressive increase in abdominal volume. Upon admission, he presented a blood glucose level of $20 \mathrm{mg} / \mathrm{dL}$. He had a medical history of type 2 diabetes mellitus, currently using metformin $850 \mathrm{mg}$ per day. As GIST treatment, he had been taking Sorafenib $800 \mathrm{mg}$ per day for about a month, as fourth-line systemic treatment. The previous systemic treatment options were Imatinib, Sunitinib and Regorafenib. Due to episodes of recurrent hypoglycemia, he was admitted to the intensive care unit (ICU). Despite of continuous replacement of $10 \%$ glucose solution, it persisted with glycemia lower than $60 \mathrm{mg} / \mathrm{dL}$, and 
treatment with glucagon $0.1 \mathrm{mg}$ per hour was started, with partial improvement of hypoglycemic episodes. Dexamethasone $12 \mathrm{mg}$ per day was associated, achieving better glycemic control, but still with occasional episodes of hypoglycemia. The serum insulin level was less than $1 \mathrm{mU} / \mathrm{L}$ with the patient's body mass index (BMI) equal to $31.55 \mathrm{~kg} / \mathrm{m}^{2}$ (reference value for BMI above $30 \mathrm{~kg} / \mathrm{m}^{2}: 2$ to $23 \mathrm{mU} / \mathrm{L}$ ) and the C-peptide value was $0.02 \mathrm{ng} / \mathrm{ml}$ (reference value: 1.1 to $4.4 \mathrm{ng} / \mathrm{ml}$ ). IGF1 was $33 \mathrm{ng} / \mathrm{mL}$ (reference value for age 25 54 years: $105-362 \mathrm{ng} / \mathrm{mL}$ ). On the $5^{\text {th }}$ day of hospitalization, no more hypoglycemia episodes occurred (Table 1). After 48 hours without a blood glucose level lower than $60 \mathrm{mg} / \mathrm{dL}$, the patient was discharged using corticosteroids (Dexamethasone 8mg per day), with a scheduled return for tumor embolization.

Table 1: Blood glucose values during hospitalization.

\begin{tabular}{|c|c|c|c|c|c|c|c|}
\hline & $\mathbf{6 H}$ & $\mathbf{8 H}$ & $\mathbf{1 2 H}$ & $\mathbf{1 8 H}$ & $\mathbf{2 2 H}$ & $\mathbf{2 4 H}$ & $\mathbf{3 H}$ \\
\hline Admission & & & 20 & 108 & & & $<20$ \\
\hline $1^{\circ} \mathrm{HD}$ & 45 & 72 & 192 & 120 & & & 54 \\
\hline $2^{\circ} \mathrm{HD}$ & 54 & 225 & 124 & 122 & 123 & 152 & 151 \\
\hline $3^{\circ} \mathrm{HD}$ & 81 & 111 & 125 & 170 & 169 & 156 & 163 \\
\hline $4^{\circ} \mathrm{HD}$ & & 80 & 132 & 94 & 125 & 143 & \\
\hline
\end{tabular}

H: Hours; HD: Hospitalization Day; Blood Glucose: mg/dL

\section{Discussion}

Hypoglycemia can be related to several tumors, including islet cell and non-islet cell tumors [2]. NICTH is a rare and serious complication of malignancy, and its presence is usually associated with a poor prognosis [2,5]. Several types of tumors are associated with NICTH, most commonly mesenchymal tumors, fibroids, carcinoids, myelomas, lymphomas, hepatocellular and colorectal carcinomas; and GIST is rarely involved [1]. Symptoms of hypoglycemia occur more frequently in the fasting state and may include confusion, lethargy, diaphoresis, or progressive drowsiness, with some patients presenting coma as the initial manifestation of hypoglycemia [5]. The diagnosis of NICTH is based on clinical and laboratory findings [5]. Medical history and physical examination can usually help to find the cause of hypoglycemia in a patient with a known tumor burden. The causes of tumoral hypoglycemia include extensive liver or adrenal infiltration by the tumor, resulting in the destruction of the liver or adrenal glands; tumor production of high levels of IGF-II; or rarely, insulin production by the tumor cells $[3,4]$. The initial laboratory evaluation includes measurement of glucose, insulin, proinsulin, C-peptide, during an episode of hypoglycemia [8]. In contrast to the biochemical findings in individuals with hyper insulinemic hypoglycemia, patients with NICTH have low serum concentrations of insulin and C-peptide during hypoglycemia $[7,8]$. There are few other disorders that cause hypoglycemia with low levels of serum insulin and C-peptide. In patients with NICTH, the plasma glucose response to glucagon administration is typically greater than $25 \mathrm{mg} / \mathrm{dL}$ [9]. If the glucose response to glucagon is less than $25 \mathrm{mg} / \mathrm{dL}$, the possibilities include extensive tumor replacement of liver tissue, resulting in low hepatic glycogen stores or an alternative mechanism $[6,9]$. The treatment of this condition is related to the tripod: correction of hypoglycemia, control of the underlying neoplasia and the prevention of recurrent hypoglycemia if the tumor cannot be controlled [5,6]. The basis of treatment is in the control of tumor malignancy. If it is not possible to perform tumor resection, other treatment options can be used to control the tumor and solve hypoglycemia, as systemic therapy, radiation, cryoablation, radiofrequency ablation or selective embolization of the blood vessels that feed the tumor [8].

In situations where the underlying malignancy cannot be treated, medications are needed to prevent recurrent symptoms of hypoglycemia. In case series and reports, hypoglycemia was controlled with glucocorticoids, glucagon or recombinant human growth hormone $[6,10]$. The somatostatin analogs and diazoxide were not effective [10]. Glucocorticoids (30 to $60 \mathrm{mg}$ daily) are a reasonable initial therapy [7]. Glucocorticoids decrease the amount of IGF-II and increase its clearance and impair the action of insulin. High-dose glucocorticoid-refractory hypoglycemia is particularly found in patients with disseminated disease [6,7]. If hypoglycemia persists, patients can use glucagon [9]. Obtaining a glycemic response to glucagon, a long-term intravenous infusion of glucagon (0.06 to $0.30 \mathrm{mg} /$ hour) is recommended [5]. Growth hormone at supraphysiological doses of 3 to $12 \mathrm{mg}$ per day has been shown to increase IGF-binding protein, which bind to IGF-II and prevent interaction with the insulin receptor, thereby reducing hypoglycemia, however, it increases IGF-I and has the potential to increase tumor growth $[4,10]$. Despite NICTH is a rare condition, it should be remembered whenever there are suggestible clinical and laboratory signs and symptoms, once it is a crucial condition and it gives the patient a worse prognosis. Its management is of unquestionable importance to ensure the patient's quality of life, given that if not treated correctly and continually, hypoglycemia can happen again and cause successive hospitalizations or even death.

\section{Acknowledgement}

1. Facanha ALBP: She reviewed the literature; she wrote the text.

2. Junior JEBR: He collected data from the patient's case report; He wrote the text.

3. Camandaroba MPG: He reviewed the literature; he wrote and edited the text.

\section{Conflict of Interest}

We declare that there was no financial interest or conflict of interest.

\section{References}

1. Michelle A, Stephen A (2014) Thyroid hormone inactivation in gastrointestinal stromal tumors. N Engl J Med 371(1): 86-87.

2. Scott K (2009) Non-islet cell tumor hypoglycemia. J Pain Symptom Manage 37(4): e1-3. 
3. Morbois-Trabut L, Maillot F, De Widerspach A, Lamisse F, Couet C (2004) Big IGF-II-induced hypoglycemia secondary to gastric adenocarcinoma. Diabetes Metab 30(3): 276-279.

4. Izumi F, Naomi H, Yukiko I, Kumiko Y, Yuko M, et al. (2006) Clinical features of insulin-like growth factor-II producing non-islet-cell tumor hypoglycemia. Growth Horm IGF Res 16(4): 211-216.

5. Timothy W, Maria J, Massimo P (2014) Management of non-islet-cell tumor hypoglycemia: A clinical review. J Clin Endocrinol Metab 99(3): 713-722.

6. Bourcigaux N, Arnault-Ouary G, Christol R, Périn L, Charbonnel B, et al (2005) Treatment of hypoglycemia using combined glucocorticoid and recombinant human growth hormone in a patient with a metastatic nonislet cell tumor hypoglycemia. Clin Ther 27(2): 246-251.
7. Teale JD, Marks V (1998) Glucocorticoid therapy suppresses abnormal secretion of big IGF-II by non-islet cell tumours inducing hypoglycaemia (NICTH). Clin Endocrinol (Oxf) 49(4): 491-498.

8. De Boer J, Jager PL, Wiggers T, Nieboer P, MacHteld W, et al. (2006) The therapeutic challenge of a nonresectable solitary fibrous tumor in a hypoglycemic patient. Int J Clin Oncol 11(6): 478-481.

9. Hoff AO, Vassilopoulou-Sellin R (1998) The role of glucagon administration in the diagnosis and treatment of patients with tumor hypoglycemia. Cancer 82(8): 1585-1592.

10. Perros P, Simpson J, Innes JA, Teale JD, McKnight JA (1996) Non-islet cell tumour-associated hypoglycaemia: 111In-octreotide imaging and efficacy of octreotide, growth hormone and glucocorticosteroids. Clin Endocrinol (Oxf) 44(6): 727-731.

For possible submissions Click below: 